\title{
EXPERIMENTAL STUDY OF THERMOPLASTIC PROPERTIES OF AGGLOMERATE
}

\author{
Vlastimil NOVÁK, Lenka ŘEHÁČKOVÁ, Petr KLUS, Bedřich SMETANA, Silvie ROSYPALOVÁ, \\ L'ubomíra DROZDOVÁ, Jana DOBROVSKÁ
}

VSB - Technical University of Ostrava, Ostrava, Czech Republic, EU, vlastimil.novak@vsb.cz

https://doi.org/10.37904/metal.2020.3449

\begin{abstract}
Traditional routes of ironmaking and steelmaking processes demand high-temperature preparatory steps, such as coking and sintering. These processes are of great concern since they represent a considerable environmental burden. As an alternative, carbon-containing iron oxides agglomerates (sinters) can be used. In this work, the assessment of thermoplastic properties of prepared sinters, especially the determination of softening and liquidus temperatures, was performed by two methods: optical and spindle drop method. For the first-mentioned method, high-temperature observation furnace CLASIC was employed, which enables observation of changes in specimen shape depending on temperature. While in the case of the second method, Furnace Rheometer System FRS 1600 was used. This system allows measuring changes of spindle height as a function of temperature when different normal forces, in specific 3 and $20 \mathrm{~N}$, are applied. Besides, analyzed sinters were of different grain sizes and contained approximately $59 \mathrm{wt} . \%$ of iron and $7.2 \mathrm{wt} . \%$ of iron(II) oxide. The samples were measured up to liquidus temperature at various heating rates in an inert atmosphere of argon gas. In summary, a good agreement between phase transformation temperatures measured by both methods was achieved, and the influence of experimental conditions on these temperatures was confirmed.
\end{abstract}

Keywords: Agglomerate, thermoplastic properties, softening temperature, melting

\section{INTRODUCTION}

Within ironmaking and steelmaking processes, one of the most critical areas throughout a blast furnace is the cohesive zone. In this region, ore sinters begin to soften and consequently melt by further heating and reduction. This zone is hardly porous, and the gas can only flow through coke lumps [1,2]. Its shape, thickness and position significantly affect furnace productivity and fuel efficiency. The temperature properties of iron ore burden are essential, given the creation of blast furnace melting-softening zone [3,4]. Usually, consideration is being given to the softening starting temperature, softening finishing temperature and melting temperature which are defined as the temperature at which burden pressure drop is about $1 \mathrm{kPa}$ or burden contraction reaches $4-10 \%$, as the temperature whereupon pressure drop falls down to $0.5 \mathrm{kPa}$ or contraction attains $40 \%$, and as the temperature when pressure drop progresses significantly $[3,5]$.

The study and knowledge of these characteristics are of great importance. The softening and melting behavior of blast furnace raw materials has been studied intensively for over five decades. During that period, various methodology approaches emerged, enabling either routine testing or more sophisticated testing of blast furnace burden materials concerning cohesive zone. Typically, the ferrous burden, together with coke, is placed in a graphite crucible and then into the vertically oriented furnace. The samples are heated under desired regimes while pressure drop throughout the burden is registered depending on temperature [5,6]. A similar experimental setup was used by Kaushik [7], where, instead of measurement of pressure, changes in sample shape were visualized using X-ray fluoroscopy. Ślęzak et al. used a high-temperature rheometer, which is intended primarily for testing rheological parameters, to determine softening temperatures by 
measuring changes in sample height as a function of temperature [8]. An alternative approach enabling observation of sample silhouettes during heating is the use of a heating microscope. In this case, temperatures of concern can be determined, for instance, under German standard 51730, where three characteristic stages of the sample are mentioned, i.e., softening temperature (implying the start of plastic deformation), hemispherical temperature (denoting liquidus temperature), and flow temperature (signifying mobility of liquid) [9].

In this work, thermoplastic properties of iron ore sinters were assessed by two methods, i.e., optical and spindle drop method. Furthermore, temperatures of softening and melting were investigated under different experimental conditions and depending on the grain size of the sample.

\section{EXPERIMENTAL RESEARCH}

\subsection{Samples characterization}

Agglomerate samples of different grain sizes were selected for experimental determination of thermoplastic properties, in particular softening and melting temperatures. Sample 1 was powder agglomerate, and sample 2 was agglomerate with a particle size of $3-5 \mathrm{~mm}$. The chemical composition of samples is listed in Table 1 .

Table 1 Chemical composition of sinters (wt.\%)

\begin{tabular}{|c|c|c|c|c|c|c|c|}
\hline Sample & $\mathbf{F e}$ & $\mathbf{F e O}$ & $\mathrm{SiO}_{\mathbf{2}}$ & $\mathbf{A l}_{2} \mathbf{O}_{3}$ & $\mathbf{M n}$ & $\mathbf{C a O}$ & $\mathbf{M g O}$ \\
\hline $\mathbf{1}$ & 58.80 & 7.29 & 7.47 & 1.24 & 0.39 & 6.38 & 1.07 \\
\hline $\mathbf{2}$ & 59.20 & 7.15 & 6.27 & 1.23 & 0.41 & 6.75 & 1.20 \\
\hline Sample & $\mathbf{P}_{2} \mathbf{O}_{5}$ & $\mathrm{Cr}_{2} \mathbf{O}_{3}$ & $\mathbf{Z n}$ & $\mathrm{K}_{2} \mathbf{O}$ & $\mathbf{S}$ & $\mathrm{Na}_{2} \mathbf{O}$ & Basicity $^{*}$ \\
\hline $\mathbf{1}$ & 0.08 & 0.03 & 0.01 & 0.09 & 0.01 & 0.09 & 0.86 \\
\hline $\mathbf{2}$ & 0.10 & 0.02 & 0.01 & 0.09 & 0.01 & 0.09 & 1.06 \\
\hline
\end{tabular}

* Calculated according to the formula: Basicity $=(\omega(\mathrm{CaO})+\omega(\mathrm{MgO})) /\left(\omega\left(\mathrm{SiO}_{2}\right)+\omega\left(\mathrm{Al}_{2} \mathrm{O}_{3}\right)\right)$, where: $\omega$ is the mass fraction of the given component (wt. \%).

\subsection{Measurement of thermoplastic properties}

The thermoplastic properties of agglomerate samples were investigated by two experimental methods, i.e., optical and spindle drop method. Within the first experimental method, tested agglomerate samples were observed during heating. Subsequently, registered changes in shape were evaluated.

Experimental measurement of melting and softening temperature was performed in a resistance observation furnace Clasic enabling measurement in a low vacuum of $<8 \cdot 10^{-3}$ mbar [10]. Agglomerate samples were placed in the furnace, which was then hermetically sealed, evacuated to approximately $0.1 \mathrm{~Pa}$ and flushed with argon gas (> 99.9999\%). The heating rate was $5{ }^{\circ} \mathrm{C} \cdot \mathrm{min}^{-1}$, and the temperature was measured by a thermocouple Pt - 13\% Rh / Pt. Experiments were carried out under an inert atmosphere of argon to prevent oxidation of the sample during measurement. The images of shape changes were captured by a camera CANON EOS20D and saved in the PC.

The second experimental method was performed using Anton Paar FRS 1600 high-temperature viscometer. This device consists of a laboratory furnace and measuring air bearing head DSR 301 . This device allows, amongst other things, measurement of spindle height as a function of temperature and a load of the sample surface with different magnitudes of the normal force. In the case of measuring the softening and melting temperatures, the normal forces were of 3 and $20 \mathrm{~N}$. The measuring system consists of a graphite spindle mounted on a long ceramic shaft connected to the rheometer head, and of a graphite crucible, which is fixed to the lower ceramic shaft. Further, the viscometer allows measurement up to temperatures of $1,550^{\circ} \mathrm{C}$, which 
are registered by a Pt-13\%Rh/Pt thermocouple. The agglomerate sample was placed in a graphite crucible and inserted into the furnace with it. In order to avoid oxidation of the sample, the argon (purity> 99.9999\%) was used at a flow rate of $150 \mathrm{l} / \mathrm{h}$. Since the effect of heating rate on temperatures in question was also tested, two heating ramps were chosen (see Table 2).

Table 2 Temperature regimes of sample heating

\begin{tabular}{|c|c|c|c|}
\hline \multicolumn{2}{|c|}{ Temperature regime 1 } & \multicolumn{2}{c|}{ Temperature regime 2 } \\
\hline Temperature interval $\left({ }^{\circ} \mathbf{C}\right)$ & Heating rate $\left({ }^{\circ} \mathbf{C} \cdot \mathbf{m i n}^{-1}\right)$ & Temperature interval $\left({ }^{\circ} \mathbf{C}\right)$ & Heating rate $\left({ }^{\circ} \mathbf{C} \cdot \mathbf{m i n}^{-1}\right)$ \\
\hline $25-1,000$ & 10 & $25-1,050$ & 15 \\
\hline $1,000-1,400$ & 2 & $1,050-1,300$ & 2 \\
\hline
\end{tabular}

\section{RESULTS AND DISCUSSION}

\subsection{Method consisting of optical observation of the sample}

Samples of the sinter were observed during heating, and the images taken at specific temperatures were evaluated. Emphasis was placed mainly on changes in the shape. Figure 1 shows the percentage reduction in the area of sample 1 as a function of temperature. The temperature when the sample shape began to deform was considered as the softening temperature, which was for this sample $1,140{ }^{\circ} \mathrm{C}$. As for the liquidus temperature, this temperature could not be determined due to significant interaction between the agglomerate sample and the graphite substrate at temperatures above $1,220^{\circ} \mathrm{C}$ (detail of Figure 2). Besides, for sample 2, the given method was not appropriate since agglomerate grains with a size of 3-5 $\mathrm{mm}$ did not hold any shape after pelleting.

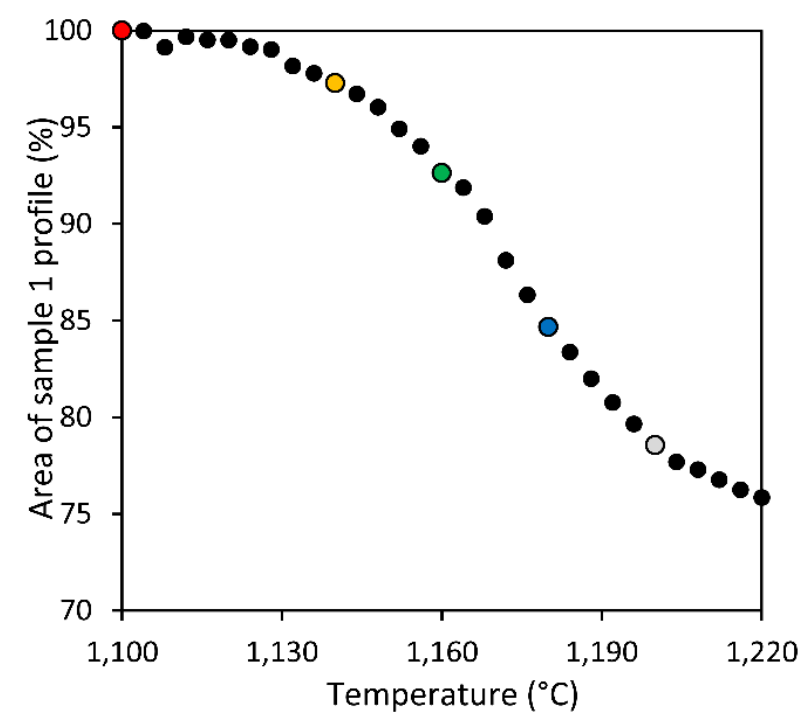

Figure 1 Dependence of sample 1 silhouettes on temperature

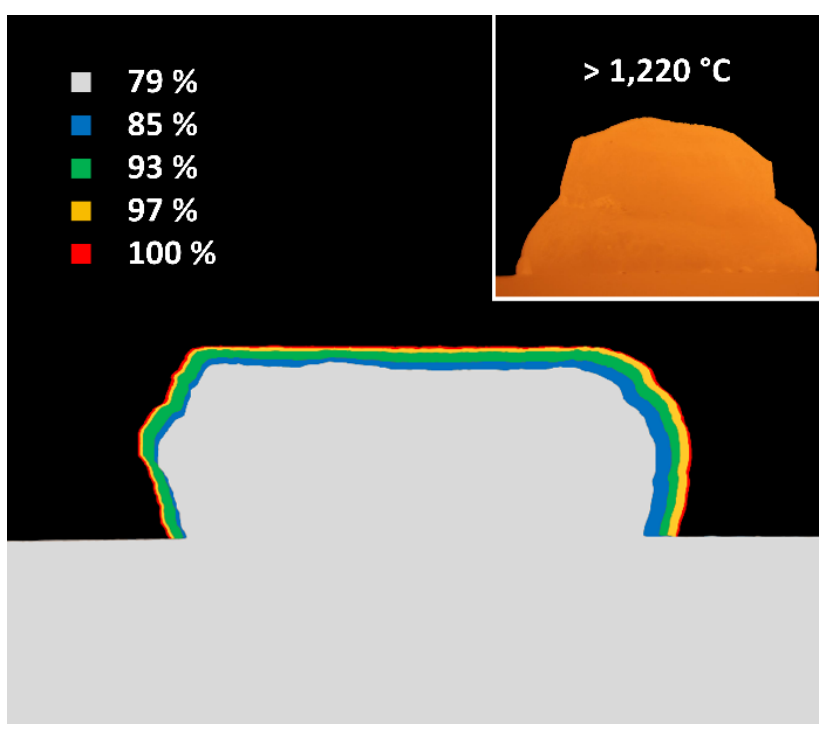

Figure 2 Silhouettes of sample 1 during heating Colors correspond to the highlighted points in Figure 1. Inlay denotes the interaction between sample and graphite substrate 


\subsection{Method based on rheological measurements}

Within the given method, various experimental conditions and their influence on softening and melting temperatures were tested. Figure 3 shows the percentage decrease of the spindle acting on the upper surface of sample 1 when the normal force of $3 \mathrm{~N}$ was applied depending on temperature. Particular curves were obtained under different temperature regimes of heating (see Table 2). The figure further provides temperature dependence of normal force and its decline to zero values pointing to liquidus temperature. Softening starting and finishing temperature was determined in two ways: either graphically by tangent method or numerically in accordance with Polish standard (BN-85/0604-16) specifying softening starting temperature as a temperature when sample height drops by $1 \%$, whereas the decline by $40 \%$ corresponds to softening finishing temperature.

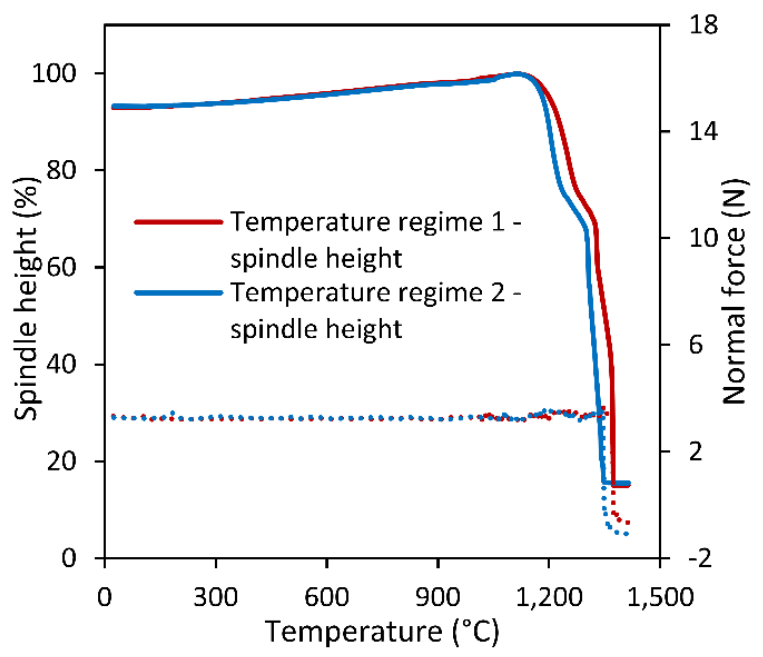

Figure 3 Effect of the temperature regime on softening and liquidus temperature (sample 1)
Table 3 Softening and liquidus temperatures at different temperature regimes

\begin{tabular}{|l|c|c|}
\hline \multirow{2}{*}{ Temperature } & \multicolumn{2}{|c|}{ Temperature regime } \\
\cline { 2 - 3 } & $\mathbf{1}$ & $\mathbf{2}$ \\
\hline $\begin{array}{l}\text { Softening starting } \\
\text { temperature }\end{array}$ & $1,156^{\circ} \mathrm{C}$ & $1,150^{\circ} \mathrm{C}$ \\
\hline $\begin{array}{l}\text { Softening starting } \\
\text { temperature }\end{array}$ & $1,158^{\circ} \mathrm{C}$ & $1,157^{\circ} \mathrm{C}$ \\
\hline $\begin{array}{l}\text { Softening finishing } \\
\text { temperature }\end{array}$ & $1,331^{\circ} \mathrm{C}$ & $1,306^{\circ} \mathrm{C}$ \\
\hline Liquidus temperature & $1,370^{\circ} \mathrm{C}$ & $1,348^{\circ} \mathrm{C}$ \\
\hline
\end{tabular}

according to Polish standard ${ }^{* *}$ determined by tangent method

In summary, both temperatures (softening and liquidus temperature) were shifted to higher values as the heating rate increased. Such a phenomenon has been documented elsewhere, e.g., in paper [11], where authors provided an approximation to equilibrium conditions to compensate this behavior. A comparison of the given temperatures is listed in Table 3.

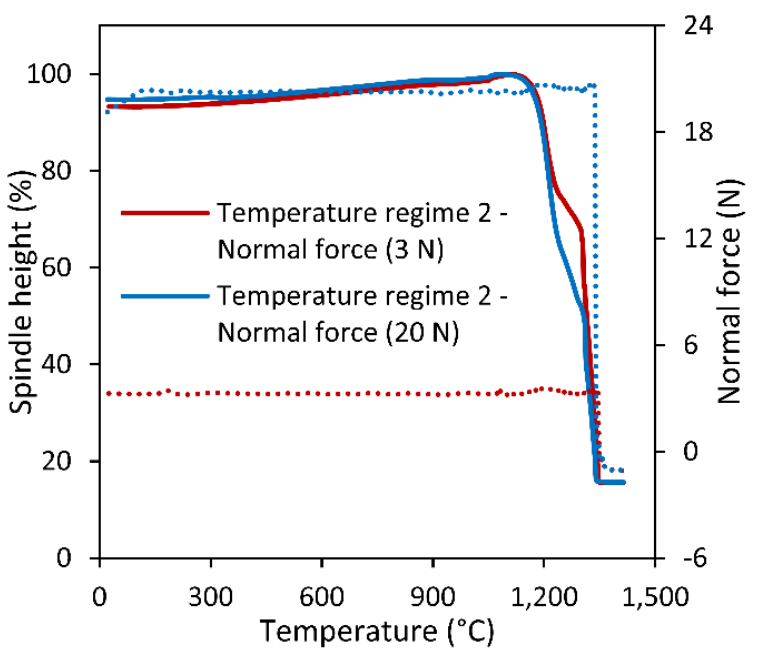

Figure 4 Assessment of the influence of normal force on liquidus and softening temperature (sample 1)
Table 4 Softening and liquidus temperatures at various applied normal forces

\begin{tabular}{|l|c|c|}
\hline \multirow{2}{*}{ Temperature } & \multicolumn{2}{|c|}{ Applied normal force } \\
\cline { 2 - 3 } & $\mathbf{3 ~ N}$ & $\mathbf{2 0 ~ N}$ \\
\hline $\begin{array}{l}\text { Softening starting } \\
\text { temperature }\end{array}$ & $1,150^{\circ} \mathrm{C}$ & $1,140^{\circ} \mathrm{C}$ \\
\hline $\begin{array}{l}\text { Softening starting } \\
\text { temperature }\end{array}$ & $1,157^{\circ} \mathrm{C}$ & $1,145^{\circ} \mathrm{C}$ \\
\hline $\begin{array}{l}\text { Softening finishing } \\
\text { temperature }\end{array}$ & $1,306^{\circ} \mathrm{C}$ & $1,264^{\circ} \mathrm{C}$ \\
\hline Liquidus temperature $^{*}$ & $1,348^{\circ} \mathrm{C}$ & $1,348^{\circ} \mathrm{C}$ \\
\hline
\end{tabular}

* according to Polish standard ${ }^{* *}$ determined by tangent method 
A comparison of the influence of normal forces ( $3 \mathrm{~N}$ and $20 \mathrm{~N}$ ), acting through the spindle on sample 1 , on the investigated temperatures can be seen in Figure 4. It is clear from this figure that increasing the value of the normal force leads to a decrease in the starting softening temperature by about $10{ }^{\circ} \mathrm{C}$, and to a decline in the finishing softening temperature by approximately $42{ }^{\circ} \mathrm{C}$. The liquidus temperature of a given sample was not affected by the change in the values of normal forces. This was confirmed by the course of normal forces as a function of temperature. Given temperatures are compared in Table 4.

The effect of different sinter particle sizes is shown in Figure 5. The given temperature dependencies were obtained when a load of $20 \mathrm{~N}$ was applied to samples 1 and 2 under heating regime 2 . It is clear from the figure that starting and finishing softening temperatures of sample 1, i.e., the sinter in the powder state, are larger than those of sample 2, i.e., the sinter with a grain size of 3-5 $\mathrm{mm}$. The softening onset temperature increased by about $45^{\circ} \mathrm{C}$, whereas the softening end temperature by less than $20^{\circ} \mathrm{C}$. Besides, the sinter particle size also slightly affected the liquidus temperature. In the case of sample 2 , the temperature was $11^{\circ} \mathrm{C}$ higher than in sample 1. These temperatures are noted in Table 5.

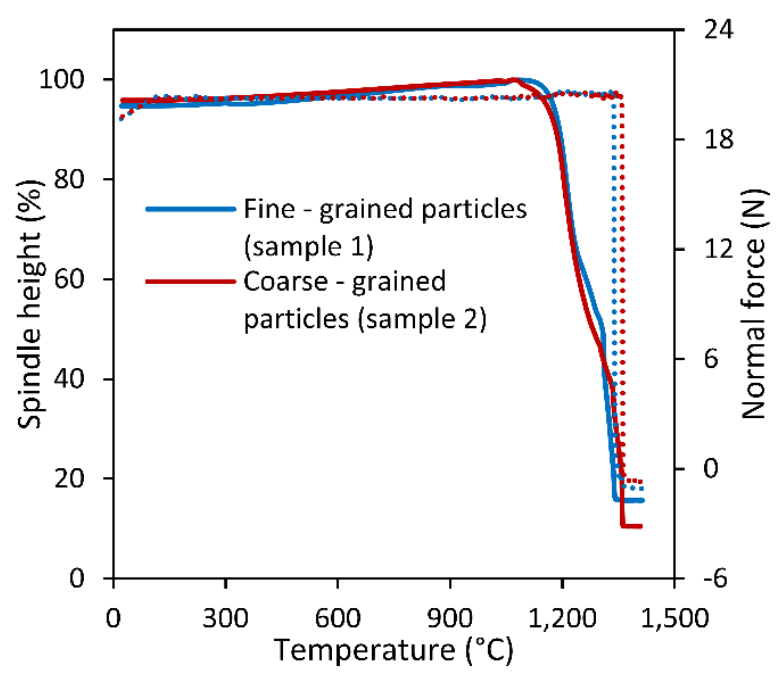

Figure 5 Influence of particle size on liquidus and softening temperature
Table 5 Softening and liquidus temperatures at varying particle sizes

\begin{tabular}{|l|c|c|}
\hline \multirow{2}{*}{ Temperature } & \multicolumn{2}{|c|}{ Particle size } \\
\cline { 2 - 3 } & Powder & $\mathbf{3 - 5} \mathbf{~ m m}$ \\
\hline $\begin{array}{l}\text { Softening starting } \\
\text { temperature }\end{array}$ & $1,140^{\circ} \mathrm{C}$ & $1,094^{\circ} \mathrm{C}$ \\
\hline $\begin{array}{l}\text { Softening starting } \\
\text { temperature }\end{array}$ & $1,145^{\circ *} \mathrm{C}$ & $1,104^{\circ} \mathrm{C}$ \\
\hline $\begin{array}{l}\text { Softening finishing } \\
\text { temperature }\end{array}$ & $1,264^{\circ} \mathrm{C}$ & $1,245^{\circ} \mathrm{C}$ \\
\hline $\begin{array}{l}\text { Liquidus temperature } \\
\text { tem }\end{array}$ & $1,348^{\circ} \mathrm{C}$ & $1,359^{\circ} \mathrm{C}$ \\
\hline
\end{tabular}

\section{CONCLUSION}

In this work, two experimental methods for determining the softening and liquidus temperatures of selected agglomerate samples were evaluated. The first method is based on optical observation of the change in sample shape during heating, while the second method takes advantage of the possibilities of rheological measurement. The results can be summarized as follows:

- $\quad$ By the optical method, it was possible to determine only the initial deformation temperature (starting softening temperature) of the examined sample. The finishing softening temperature and liquidus temperature could not be determined by this method owing to strong interaction on the sinter/graphite substrate interface.

- The influence of experimental conditions (heating rate, normal force, and sample grain size) on the resulting values of starting and finishing softening temperatures and liquidus temperature was investigated using rheological measurements.

- It was disclosed that a larger heating rate shifts the mentioned temperatures towards higher values. 
- $\quad$ Loading the sample with a higher normal force leads to a shift of softening temperatures to lower values. Nevertheless, the magnitude of the load does not affect the liquidus temperature of the examined samples.

- The effect of the sinter grain size on the values of the investigated temperatures was also confirmed. Regarding the sinter with a grain size of 3-5 mm, starting and finishing softening temperatures were lower than in the case of the sinter in the powder state. On the other hand, the liquidus temperature was $11^{\circ} \mathrm{C}$ higher for coarse agglomerate particles.

\section{ACKNOWLEDGEMENTS}

This paper was created within the frame of the project No. CZ.02.1.01/0.0/0.0/17_049/0008399 from the $E U$ and CR financial funds provided by the Operational Programme Research, Development and Education, Call 02_17_049 Long-Term Intersectoral Cooperation for ITI, Managing Authority: Czech Republic - Ministry of Education, Youth and Sports, the project GACR reg. number 17-18668S, and the student projects SGS SP2020/89.

\section{REFERENCES}

[1] GUHA, M., SINHA, M. Tracking softening-melting behaviour of blast furnace burden. ISIJ International. 2015 , vol. 55, no. 9, pp. 2033-2035.

[2] NOGUEIRA FP, FRUEHAN JR. Blast furnace burden softening and melting phenomena: part I pellet bulk interaction observation. Metallurgical and Materials Transactions B. 2004, vol. 35, no. 5, pp. 829-838.

[3] NISHIMURA, T., HIGUCHI, K., NAITO, M., KUNITOMO, K. Evaluation of softening, shrinking and melting reduction behavior of raw materials for blast furnace. ISIJ International. 2011, vol. 51, no. 8, pp. 1316-1321.

[4] MORI, K., HIDAKA, R., KAWAI, Y. The behavior of softening and melting of hematite pellet and sinter during heating in a reducing atmosphere. Transactions of the Iron and Steel Institute of Japan. 1982, vol. 22, no. 3, pp. 198-206.

[5] LIU, X., WU, S., HUANG, W., ZHANG, K., DU, K. Influence of high temperature interaction between sinter and lump ores on the formation behavior of primary-slags in blast furnace. ISIJ International. 2014, vol. 54, no. 9, pp. 2089-2096.

[6] GUO, H., SHEN, F., ZHANG, H., GAO, Q., JIANG, X. High-temperature reduction and melting mechanism of sinter with different $\mathrm{MgO}$ content. Metals. 2019, vol. 9, no. 5, art. no. 510.

[7] KAUSHIK, P., FRUEHAN, R.J. Mixed burden softening and melting phenomena in blast furnace operation Part 1 X-ray observation of ferrous burden. Ironmaking and Steelmaking. 2006, vol. 33, no. 6, pp. 507-519.

[8] ŚLEZZAK, W., KOROLCZUK-HEJNAK, M., MIGAS, P., KARBOWNICZEK, M. Determining the softening range of burden materials for the blast furnace. In METAL 2014: 23rd International Conference on Metallurgy and Materials. Ostrava: TANGER, 2014, pp. 186-191.

[9] SAGADIN, C., LUIDOLD, S., WAGNER, C., WENZL, C. Melting behaviour of ferronickel slags. JOM. 2016, vol. 68, no. 12, pp. 3022-3028.

[10] ŘEHÁČKOVÁ, L., NOVÁK, V., SMETANA, B., MATÝSEK, D., VÁŇOVÁ, P., DROZDOVÁ, L'., DOBROVSKÁ, J. Possibilities of complex experimental study of thermophysical and thermodynamic properties of selected steels. Journal of Materials Research and Technology. 2019, vol. 8, no. 4, pp. 3635-3643.

[11] DROZDOVÁ, L'., SMETANA, B., ZLÁ, S., NOVÁK, V., KAWULOKOVÁ, M., ROSYPALOVÁ, S., ŘEHÁČKOVÁ, L., MARTINÍK, O., DOSTÁL, P. Study of phase transformation temperatures of alloys based on Fe-C-Cr in hightemperature area. Journal of Thermal Analysis and Calorimetry. 2018, vol. 133, no. 1, pp. 41-48. 